\title{
41NA197, the Sam Stripling Site, on Bayou Loco in Nacogdoches County, Texas
}

Timothy K. Perttula

Follow this and additional works at: https://scholarworks.sfasu.edu/ita

Part of the American Material Culture Commons, Archaeological Anthropology Commons, Environmental Studies Commons, Other American Studies Commons, Other Arts and Humanities Commons, Other History of Art, Architecture, and Archaeology Commons, and the United States History Commons

Tell us how this article helped you.

This Article is brought to you for free and open access by the Center for Regional Heritage Research at SFA ScholarWorks. It has been accepted for inclusion in Index of Texas Archaeology: Open Access Gray Literature from the Lone Star State by an authorized editor of SFA ScholarWorks. For more information, please contact cdsscholarworks@sfasu.edu. 
41NA197, the Sam Stripling Site, on Bayou Loco in Nacogdoches County, Texas

Creative Commons License

(c) $)(1)$ (9)

This work is licensed under a Creative Commons Attribution-NonCommercial 4.0 International License 


\section{NA197, the Sam Stripling Site, on Bayou Loco in Nacogdoches County, Texas}

Timothy K. Perttula

\section{Introduction}

The Sam Stripling site (41NA197) is an ancestral Caddo settlement on a series of alluvial knolls in the floodplain on the east side of Bayou Loco in the Angelina River basin in the East Texas Pineywoods (Figure 1). The site was first located by Robert L. Turner, Sr. and Jr. in 1938, and in 1939 they told Gus Arnold of the University of Texas about the site when Arnold was conducting a Works Progress Administration (WPA)-sponsored archaeological survey of East Texas. Arnold collected a large sample of ceramic vessel sherds from the site (ET-601) during his 1939 survey work, and these collections are held by the Texas Archeological Research Laboratory at The University of Texas at Austin; the Turner's had also amassed a substantial collection during their work; and in 1996 Tom Middlebrook returned to the site and officially recorded it (Middlebrook 1996), noting a well-preserved midden deposit in one part of the site, while also inventorying the Turner's collection. In this article, I discuss the specific character of the ancestral Caddo ceramic assemblage from the Sam Stripling site recovered during Arnold's work. Analyses by Middlebrook of the other known collections from the site are in progress.

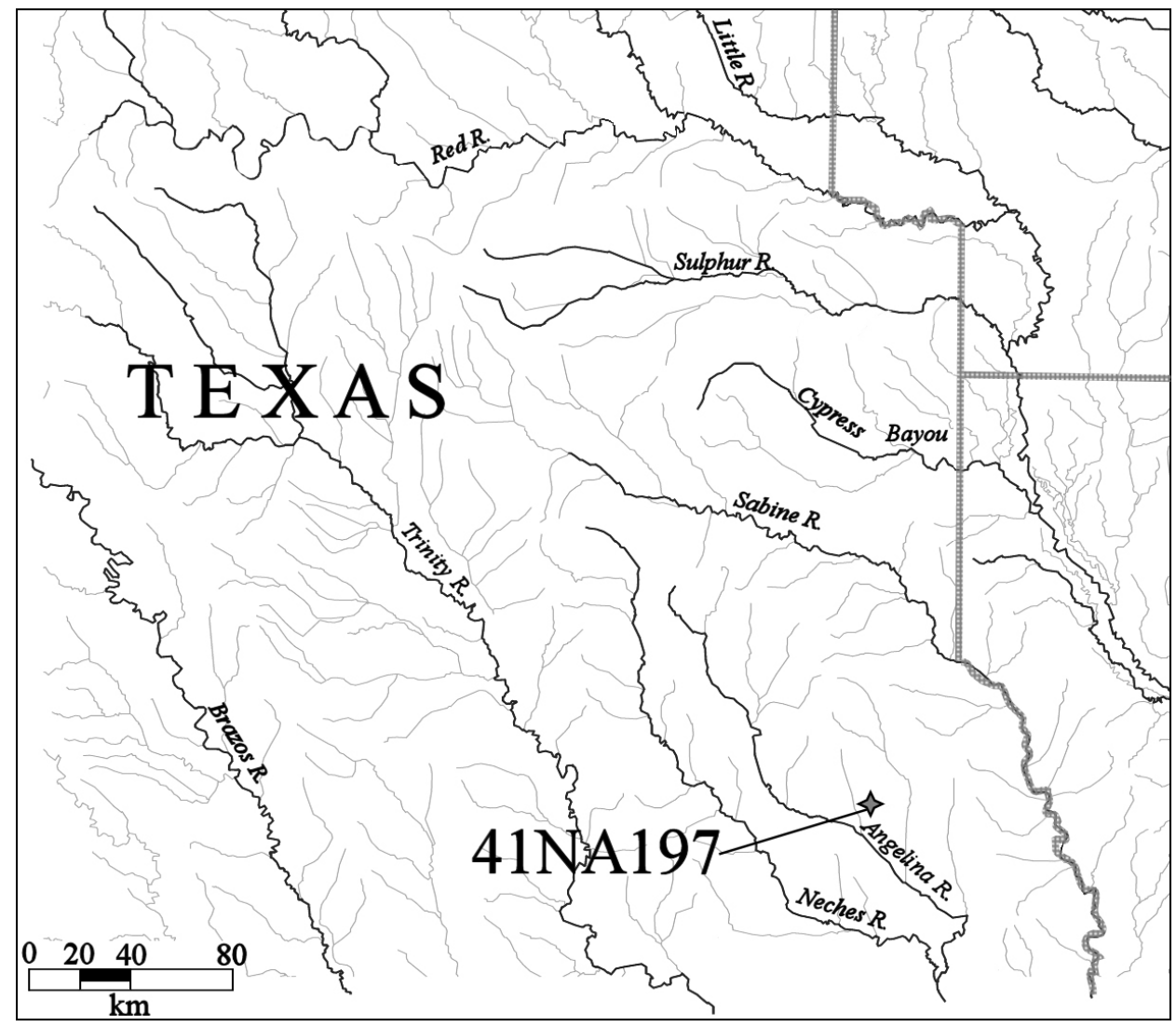

Figure 1. General location of the Sam Stripling site (41NA197) in East Texas. 


\section{Past Investigations at the Sam Stripling Site}

As part of the WPA-sponsored projects by The University of Texas between 1938-1941 (Guy 1990:Table 4), Gus Arnold completed archaeological surveys in 16 East Texas counties, including Nacogdoches County. The artifact collections from those surveys are curated at the Texas Archeological Research Laboratory at The University of Texas at Austin (TARL). Gus Arnold identified and recorded a number of ancestral Caddo sites during his 1939-1940 WPA-sponsored archaeological survey of East Texas (Im 1975). He typically identified and recorded sites in plowed fields, and made substantial artifact surface collections (Perttula 2017). He was at the Sam Stripling site in the latter part of 1939.

\section{The Gus Arnold Vessel Sherd Assemblage}

The Gus Arnold ceramic vessel sherd assemblage from the Sam Stripling site includes 313 sherds (Table 1). Ten of the sherds (3.2 percent) are from Woodland period Goose Creek Plain, var. unspecified (Story 1990) vessels, indicating a use of the site by Mossy Grove culture peoples sometime between ca. 500 B.C. and A.D. 800. The remaining 303 sherds are from tempered ancestral Caddo vessels.

Table 1. Ceramic wares and temper categories in the Gus Arnold ceramic vessel assemblage from the Sam Stripling site (41NA197).

\begin{tabular}{lllllllll}
\hline Ware & \multicolumn{7}{c}{ Temper and paste } \\
& G* & G-B & G-H & G-B-H & B & B-H & SP & N \\
\hline Plain & 142 & 9 & 12 & 1 & 3 & 2 & 10 & 179 \\
Utility & 93 & 17 & 4 & 1 & 7 & 1 & - & 123 \\
Fine & 11 & - & - & - & - & - & - & 11 \\
\hline Totals & 246 & 26 & 16 & 2 & 10 & 3 & 10 & 313 \\
\hline
\end{tabular}

*G=grog; G-B=grog-bone; G-H=grog-hematite; G-B-H=grog-bone-hematite; B=bone; $\mathrm{B}-\mathrm{H}=$ =bone-hematite; SP=sandy paste

The ancestral Caddo sherds are from plain wares, utility wares, and fine wares tempered with various combinations of grog, bone, and hematite. Almost 96 percent of the sherds are from vessels with grog temper, either as the sole temper, or in association with bone or hematite (see Table 1). The remaining 4.3 percent of the sherds have bone or hematite temper. In the assemblage as a whole, because of the use of multiple tempers in the manufacture of individual vessels, 13.6 percent of the vessel sherds have bone temper, and 7.0 percent have crushed hematite temper.

The plain to decorated sherd ratio in the ancestral Caddo vessel sherd assemblage is $1.26(169 / 134)$, and about 92 percent of the decorated sherds $(n=134)$ are from utility ware vessels with wet paste decorative elements. Fine ware sherds comprise 8.2 percent of the Gus Arnold assemblage from the Sam Stripling site (see Table 1).

The utility ware sherds $(n=123)$ in the Arnold collection from the site are primarily from vessels with incised lines $(n=37,30$ percent of the utility wares), brushed marks $(n=31,25.2$ percent $)$, brushedincised marks and lines ( $\mathrm{n}=17,13.8$ percent), and rows of tool punctations ( $\mathrm{n}=17,13.8$ percent) (Table 2). Oher utility wares have brushed-appliqued, brushed-incised-punctated, brushed-punctated, fingernail punctated, incised-punctated, and pinched decorative elements. The fine wares $(n=11)$ have engraved $(n=10,90.9$ percent of the fine wares) and trailed $(n=1)$ decorative elements. 
Table 2. Decorative methods and elements in the utility ware and fine ware sherds from the Gus Arnold assemblage at the Sam Stripling site (41NA197).

\begin{tabular}{llll}
\hline Decorative method and elements & Rim & Body & N \\
\hline
\end{tabular}

\section{Utility Ware}

Brushed

overlapping brushed marks

parallel brushed marks

vertical brushed marks

$\begin{array}{lll}- & 2 & 2 \\ - & 28 & 28 \\ - & 1 & 1\end{array}$

\section{Brushed-Appliqued}

parallel brushed marks and straight appliqued fillet

\section{Brushed-Incised}

horizontal brushed-incised marks and lines

opposed brushed-incised marks and lines

parallel brushed-incised marks and lines

parallel brushed marks and overlying opposed incised

lines

Brushed-Incised-Punctated

horizontal brushed-incised marks and lines and tool punctated row under the lip

parallel brushed-incised marks and lines and tool

punctated row through the brushed-incised el.

\section{Brushed-Punctated}

diagonal brushed marks and horizontal tool punctated

row

horizontal brushed marks and tool punctated row under the lip

opposed brushed marks and tool punctated row through the brushing

parallel brushed marks and horizontal-vertical tool

punctated rows through the brushing

parallel brushed marks and tool punctated rows through the brushing

\section{Incised}

cross-hatched incised lines

horizontal incised lines

opposed incised lines

parallel incised lines

straight incised lines

vertical and diagonal opposed incised lines

$\begin{array}{lll}1 & - & 1 \\ - & 3 & 3 \\ - & 8 & 8 \\ - & 5 & 5\end{array}$

\section{Incised-Punctated}

cross-hatched incised lines and zone of tool punctations

broad curvilinear incised lines with a zone of cane

punctations

curvilinear-diagonal incised lines and zone of fingernail punctations 
Table 2. Decorative methods and elements in the utility ware and fine ware sherds from the Gus Arnold assemblage at the Sam Stripling site (41NA197), cont.

\begin{tabular}{|c|c|c|c|}
\hline Decorative method and elements & Rim & Body & $\mathrm{N}$ \\
\hline $\begin{array}{l}\text { diagonal incised lines with overlying fingernail } \\
\text { punctations }\end{array}$ & 1 & - & 1 \\
\hline $\begin{array}{l}\text { diagonal opposed incised lines and triangular zones filled } \\
\text { with punctations }\end{array}$ & 3 & - & 3 \\
\hline parallel incised lines and tool punctated row & - & 1 & 1 \\
\hline straight incised line and $3+$ tool punctated rows & - & 1 & 1 \\
\hline \multicolumn{4}{|l|}{ Pinched } \\
\hline vertical pinched ridges & - & 1 & 1 \\
\hline \multicolumn{4}{|l|}{ Punctated } \\
\hline fingernail punctated rows & - & 3 & 3 \\
\hline tool punctated rows & - & 16 & 16 \\
\hline $3+$ tool punctated rows & 1 & - & 1 \\
\hline \multicolumn{4}{|l|}{ Fine Ware } \\
\hline \multicolumn{4}{|l|}{ Engraved } \\
\hline cross-hatched engraved lines & - & 1 & 1 \\
\hline diagonal engraved line & - & 1 & 1 \\
\hline $\begin{array}{l}\text { diagonal opposed engraved lines-large triangular excised } \\
\text { area (Holly Fine Engraved) }\end{array}$ & 1 & 1 & 2 \\
\hline opposed and curvilinear engraved lines & - & 2 & 2 \\
\hline parallel engraved lines & - & 1 & 1 \\
\hline straight engraved line & - & 1 & 1 \\
\hline straight engraved line and excised area & - & 1 & 1 \\
\hline $\begin{array}{l}\text { vertical-diagonal engraved lines and hatched curvilinear } \\
\text { zone }\end{array}$ & - & 1 & 1 \\
\hline \multicolumn{4}{|l|}{ Trailed } \\
\hline parallel trailed lines & - & 1 & 1 \\
\hline Totals & 15 & 119 & 134 \\
\hline
\end{tabular}

The sherds with brushed, brushed-incised-punctated, and brushed-punctated decorative elements (see Table 2) are from Bullard Brushed vessels with brushed and brushed-incised marks and lines on the rim and body. Occasionally, a row or rows of tool punctations were added to the decoration, either as a row beneath the vessel lip or at the rim-body juncture, or in rows pushed through the brushing. Five sherds are from early Historic Caddo period Spradley Brushed-Incised vessels with opposed incised lines overlain on brushed marks (Marceaux 2011; Perttula and Selden 2014).

Rims with incised lines have either horizontal (Figure 2a) or cross-hatched (Figure 2b) lines. Those with horizontal incised lines are likely from Early Caddo period Davis Incised vessels, and those with cross-hatched lines may be from Dunkin Incised vessels (see Suhm and Jelks 1962:Plates 18 and 19i). One body sherd is from a Pease Brushed-Incised vessel with vertical and diagonal opposed incised lines (Figure 2c; see also Suhm and Jelks 1962:Plate 60i, k). Other incised body sherds have only opposed, parallel, or straight lines (see Table 2). 

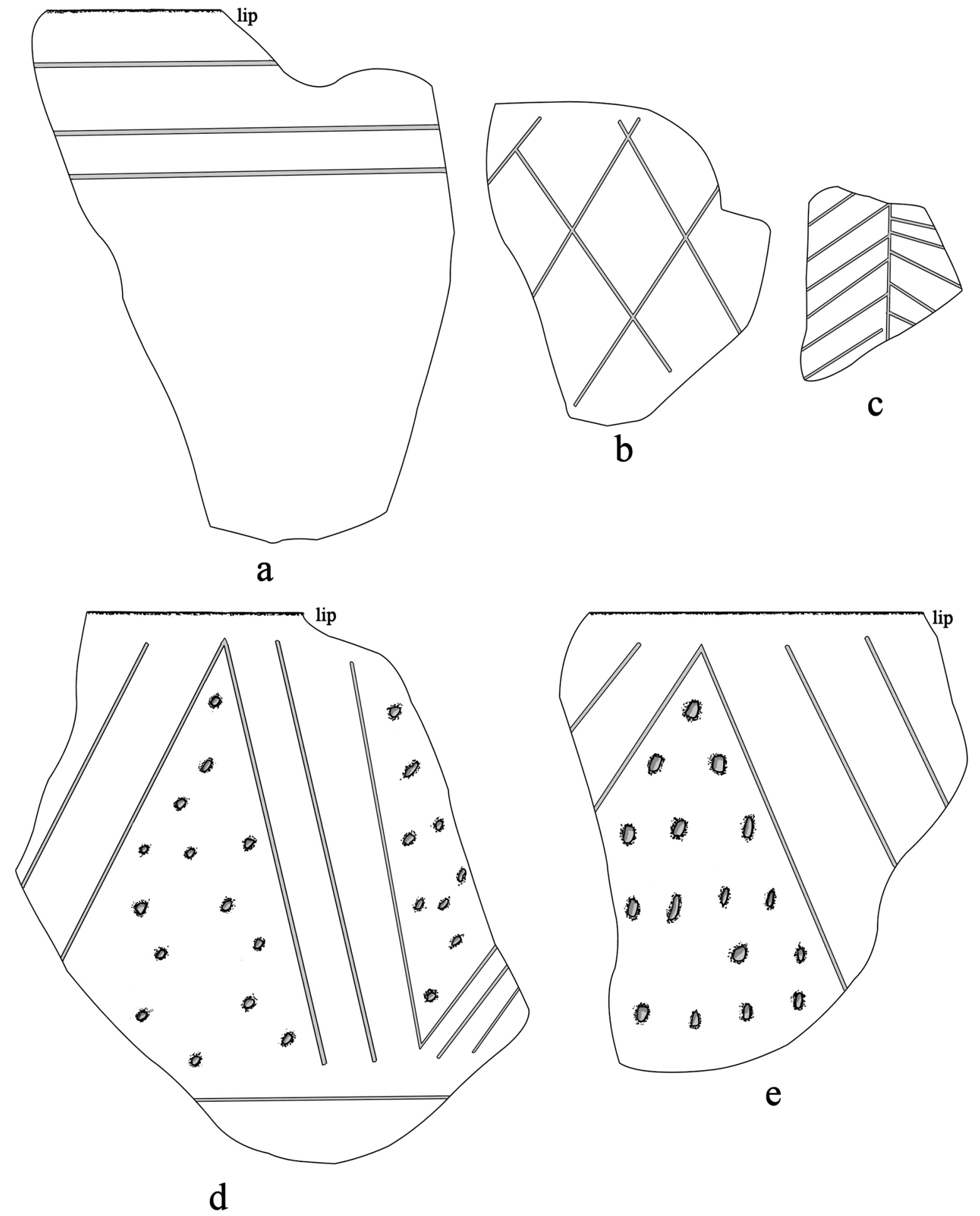

Figure 2. Decorative elements on selected utility ware sherds in the Gus Arnold assemblage from the Sam Stripling site: a-c, incised; d-e, incised-punctated. 
The rim sherds with incised-punctated decorative elements have diagonal opposed incised lines (straight to curvilinear lines) with triangular zones between the lines filled with rows of tool punctations (see Figures 2d-e and Figure 3a). They are from either Maydelle Incised or Pineland Punctated-Incised vessels (Suhm and Jelks 1962:Plate 52; Jelks 2017:Figure 29). Two other rim sherds have either curvilinear-diagonal incised lines and a zone of fingernail punctations (see Figure 3c) or diagonal incised lines with overlying fingernail punctations (see Figure $3 b$ ).
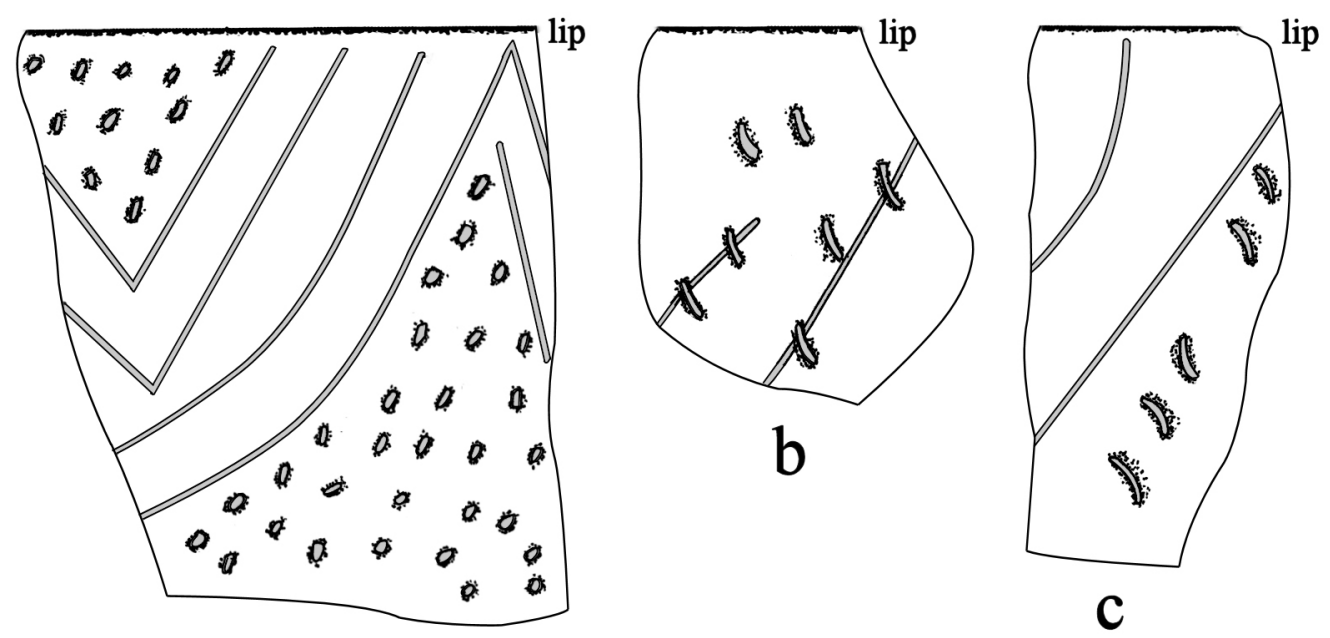

a

Figure 3. Incised-punctated rim sherds in the Gus Arnold assemblage from the Sam Stripling site.

A body sherd from one of these types has cross-hatched incised lines and a zone of tool punctations. Another body sherd has parallel incised lines adjacent to a row of tool punctations, and another from the Arnold assemblage has a straight incised line adjacent to at least three punctated rows (see Table 2). Lastly, one body sherd has broad curvilinear incised lines with a zone of cane punctations, and this sherd may be from an early Caddo Crockett Curvilinear Incised vessel (see Suhm and Jelks 1962:Plate 17d, h-i).

One utility ware body sherd is from a Killough Pinched jar (see Suhm and Jelks 1962:Plate 46). It has vertical pinched ridges (see Table 2). Eighty-five percent of the punctated sherds in the Arnold assemblage have rows of tool punctations (likely including cut fish vertebrae as tools, see Dumas [2017]), probably on both the rim and the vessel body; the remaining punctated sherds (15 percent) have rows of fingernail punctations.

Two of the fine ware engraved sherds are from Early Caddo period Holly Fine Engraved carinated bowls that have diagonal opposed engraved lines and large triangular excised areas (Figure 4a; see also Suhm and Jelks 1962:Plates 39 and 40). Several of the other sherds may also be from Holly Fine Engraved vessels, including a body sherd with a diagonal engraved line and a body sherd with a straight engraved line and an excised area (see Table 2).

Another engraved body sherd in the Gus Arnold assemblage has cross-hatched engraved lines, one body sherd from a carinated bowl has opposed and curvilinear engraved lines (see Figure 4c), and a third body sherd (from a bottle) has vertical and diagonal engraved lines and a curvilinear engraved zone with hatched lines (see Figure 4b). There are also two sherds with either parallel or straight engraved lines (see Table 2).

The one remaining fine ware sherd in the Gus Arnold assemblage from the Sam Stripling site is a body sherd from a Keno Trailed, var. unspecified vessel. The sherd has parallel trailed lines (see Table 2). 

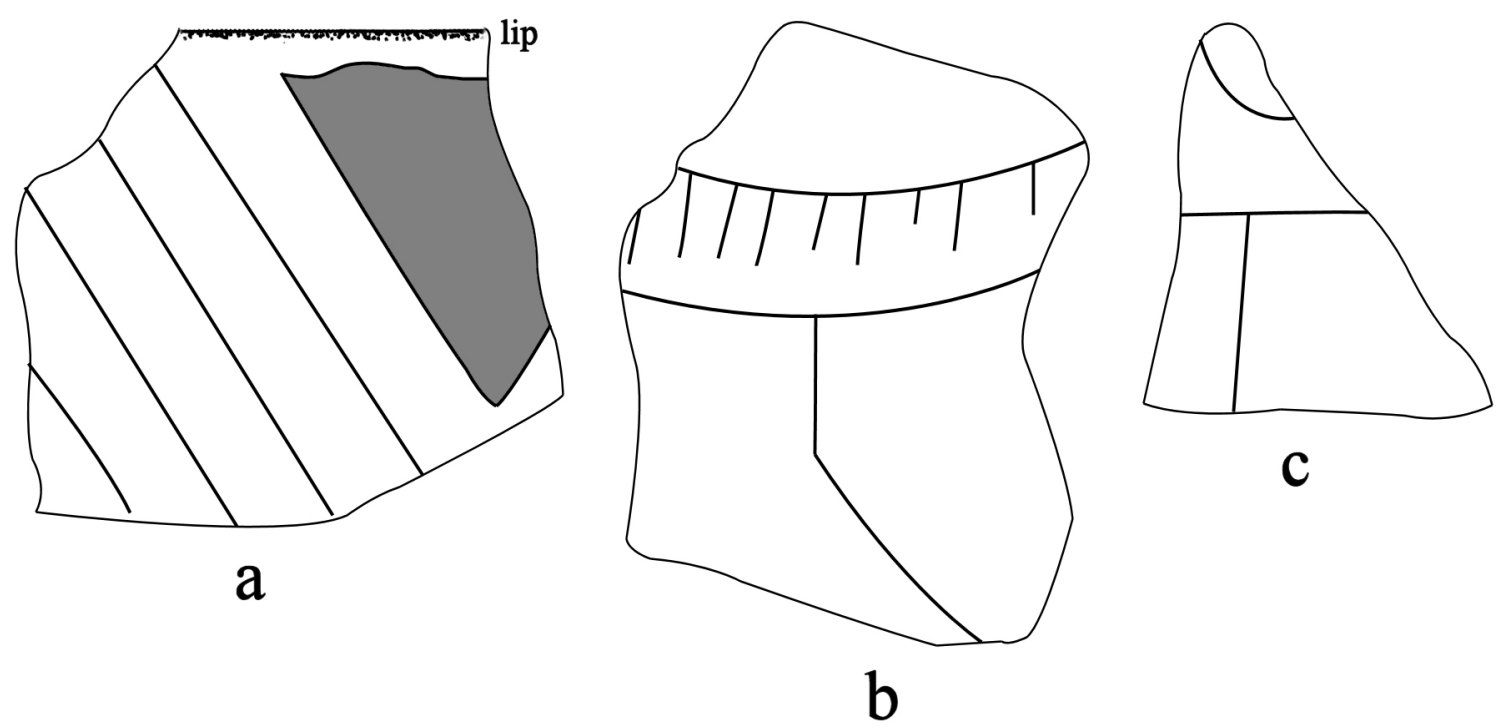

Figure 4. Decorative elements on selected engraved fine ware sherds in the Gus Arnold assemblage from the Sam Stripling site: a, Holly Fine Engraved rim sherd; b, engraved carinated bowl sherd; c, engraved bottle sherd.

\section{Summary and Conclusions}

In 1939, during a WPA project regarding the archaeological survey of East Texas, Gus Arnold of the University of Texas visited the Sam Stripling site (41NA197) on knolls in the Bayou Loco floodplain, and collected a substantial assemblage of aboriginal ceramic vessel sherds there. This sherd assemblage is in the collections at the Texas Archeological Research Laboratory at The University of Texas at Austin, where I had the opportunity to analyze the sherd assemblage $(n=313)$.

About 3 percent of the sherds are from a Woodland period (ca. 500 B .C.-A.D. 800) Mossy Grove occupation of the Sam Stripling site. The sherds are from sandy paste Goose Creek Plain, var. unspecified vessels. The remainder of the ceramic sherds are from ancestral Caddo vessels discarded at the site during several different occupations. The first occupation by Caddo peoples at the site took place during the Early Caddo period (ca. A.D. 900-1200), and is marked by sherds from Crockett Curvilinear Incised, Dunkin Incised, and Holly Fine Engraved vessels.

The principal occupation by ancestral Caddo peoples at the Sam Stripling site was during the Late Caddo period Frankston phase (ca. A.D. 1400-1680). The ceramic vessel sherd assemblage, primarily from grog-tempered vessels, in this component had a considerable number of utility ware jars with brushed, brushed-incised, brushed-punctated, and tool punctated decorative elements from Bullard Brushed, Killough Pinched, Maydelle Incised or Pineland Punctated-Incised, and Pease Brushed-Incised types. About 45 percent of the utility ware sherds at the site have brushing marks.

The third and last ancestral Caddo occupation at the Sam Stripling site took place after ca. A.D. 1680 during the Historic Caddo Allen phase. The few sherds identified from this occupation are from Spradley Brushed-Incised jar sherds and a Keno Trailed, var. unspecified body sherd.

\section{Acknowledgments}

Thanks to Lauren Bussiere for facilitating access to the Gus E. Arnold WPA collections at TARL from 41NA197. Lance Trask prepared the figures in this article. 


\section{References Cited}

Dumas, A. A.

2017 A Case Study on the Use of Fish Bones for Decorating Southeastern US Pottery. La Tinaja (A Newsletter of Archaeological Ceramics) 22(2):1-8.

Guy, J. A.

1990 Previous Archeological Investigations. In The Archeology and Bioarcheology of the Gulf Coastal Plain, by D. A. Story, J. A Guy, B. A. Burnett, M. D. Freeman, J. C. Rose, D. G. Steele, B. W. Olive, and K. J. Reinhard, pp. 27-130. Research Series No. 38. 2 Vols. Arkansas Archeological Survey, Fayetteville.

Im, H.-J,

1975 An Analysis of the G. E. Arnold Survey of East Texas. Master's thesis, Department of Anthropology, The University of Texas at Austin.

Jelks, E. B.

2017 The Archaeology of Sam Rayburn Reservoir. Volume 3, Article 1. CRHR Research Reports. Center for Regional Heritage Research, Stephen F. Austin State University, Nacogdoches. http://scholarworks. sfasu.edu/crhr_research_reports/vol3/iss1/1.

Marceaux, P. S.

2011 The Archaeology and Ethnohistory of the Hasinai Caddo: Material Culture and the Course of European Contact. Ph.D. dissertation, Department of Anthropology, The University of Texas at Austin.

Middlebrook, T.

1996 Location is Everything in Archaeology: The Case of the Sam Stripling Site. Paper presented at the 1996 East Texas Archeological Conference, Tyler, Texas.

Perttula, T. K.

2017 Current Archeological Research in East Texas: Documentation of WPA-Gus Arnold Archeological Survey Collections. Caddo Archeology Journal 27:100-101.

Perttula, T. K. and R. Z. Selden, Jr.

2014 Ancestral Caddo Ceramics in East Texas. Journal of Northeast Texas Archaeology 48:9-58.

Story, D. A.

1990 Cultural History of the Native Americans. In The Archeology and Bioarcheology of the Gulf Coastal Plain, by D. A. Story, J. A Guy, B. A. Burnett, M. D. Freeman, J. C. Rose, D. G. Steele, B. W. Olive, and K. J. Reinhard, pp. 163-366. Research Series No. 38. 2 Vols. Arkansas Archeological Survey, Fayetteville.

Suhm, D. A. and E. B. Jelks (editors)

1962 Handbook of Texas Archeology: Type Descriptions. Special Publication No. 1, Texas Archeological Society, and Bulletin No. 4, Texas Memorial Museum, Austin. 